\title{
Application of solar organic Rankine system for energy generation in buildings: the case of Athens
}

\author{
G.K. Alexis*, E.I. Sfinias
}

\begin{abstract}
This paper describes the performance of an ORC system driven by solar energy and R134a as working fluid. The system is predicted along the twelve months of the year. The operation of the system and the related thermodynamics are simulated by suitable computer codes and the required local climate data are determined by statistical processing over a considerable number of years. It's found that the solar to electricity efficiency of this SORC system varies from 0.049 to 0.058 while the ambient temperature varies from $11.3^{\circ} \mathrm{C}$ to $29.2^{\circ} \mathrm{C}$ and the total solar irradiance varies from $443 \mathrm{~W} / \mathrm{m}^{2}$ to $679 \mathrm{~W} / \mathrm{m}^{2}$. The system's arrangement comprises a solar thermal array which is coupled with an organic Rankine engine. The mean annual overall efficiency of the SORC system is estimated at 0.055 while the thermodynamic efficiency of Rankine is calculated at 0.107 . The obvious advantage of this arrangement is that electricity can be produced in buildings by using the existing common solar thermals installed. Easy-to-find machinery is employed in order to attain a simple and practical small-scale organic Rankine cycle arrangement coupled with common solar thermals used widely in Greek buildings for DHW production and space heating assistance.
\end{abstract}

Keywords - Solar Organic Rankine, Rankine cycle, Solar energy, Solar thermals

\section{INTRODUCTION}

Many international studies and experience have shown that solar thermal power plants are the most economic form of the solar electricity generation. Past researches have concluded that the SORC is a very promising technology. More precisely, a SORC system with scroll expander and working medium R113 has been proposed for small distributed power generation systems and according to the experimental results of this work, the total mechanical power generation efficiency of the system can reach 7\% [1]. In addition, the performance data of the experimental campaigns carried out during a work concerned the organic Rankine in different operational conditions showed that a maximum overall solar-to-electricity efficiency of $8 \%$ is achievable in SORC for small scale applications [2]. A small-scale system designed to generate electricity from low temperature heat (e.g., solar energy) has been described [3]. The system operates on the Rankine cycle and uses n-pentane as the working fluid. A prototype system has been designed, constructed and tested. It is capable of delivering $1.5 \mathrm{~kW}$ of electricity with a thermal efficiency of $4.3 \%$. Furthermore Greece has an excellent solar potential which enables the ORC engine to perform high efficiencies throughout the year.

G.K. Alexis is with the University of West Attica, Dept. of Mechanical Engineering, Campus II, 250 Thivon \& P. Ralli, 12244 Athens, Greece. *Corresponding author: E-mail: galexis@uniwa.gr, Fax: +30210538

E.I. Sfinias is with the University of West Attica, Dept. of Mechanical Engineering, Campus II, 250 Thivon \& P. Ralli, 12244 Athens, Greece
A SORC model for reverse osmosis desalination was designed [4] and its experimental evaluation by the project elaborated in Greece has proven a $4 \%$ overall system efficiency with a theoretical efficiency of the ideal Rankine at $10 \%$ [5]. A dynamic simulation model of a novel prototype of a $6 \mathrm{kWe}$ solar power plant has been presented [6]. The system is based on the coupling of solar thermal collectors with a small Organic Rankine Cycle (ORC), simultaneously producing electric energy and low temperature heat. The solar field consists of about $73.5 \mathrm{~m}^{2}$ of flat-plate evacuated solar collectors, heating a diathermic oil up to a maximum temperature of $230^{\circ} \mathrm{C}$. The results show that the efficiency of the ORC does not significantly vary during the year, remaining always close to $10 \%$. A sensitivity analysis confirmed that the system may be economically feasible for the majority of locations in the Mediterranean area, whereas the profitability is unsatisfactory for Central-Europe sites.

\section{TECHNICAL AND FUNCTIONAL CHARACTERISTICS OF THE SYSTEM}

The components and the operation of the SORC system, which is concerned in the present work, are illustrated in Figure 1.

The fluid in the solar thermal circuit is water and the working fluid in the Rankine circuit is R134a. In the present study, the refrigerant $\mathrm{R} 134 \mathrm{a}$ is selected to be the working fluid for the organic Rankine engine because of the abilities as well as the restrictions related to the operation and the working conditions of the solar thermals. The organic fluid R134a is a refrigerant which has a boiling point at $26.5^{\circ} \mathrm{C}$ and a critical temperature at $101.1^{\circ} \mathrm{C}$. The Soave's equation has been applied in order to determine the thermodynamics properties of R134a at each point of the theoretical Rankine cycle. The selection of the working fluid is crucial for the efficiency of the cycle and R134a fits in small scale solar applications [7]. The thermodynamic properties of R134a make the Rankine cycle very efficient at temperatures lower than $100^{\circ} \mathrm{C}$ [8]. Besides, R134a is classified into A1 safety group of ASHRAE 34 because is low toxic, low corrosive, non-flammable, non- explosive, rather stable chemically and thermally and it is considered an environmental friendly material [9]. The solar thermal array consists of vacuum tube collectors which convert the solar power into heat and they provide hot water to the buffer which is a thermally stratified tank. When the storage tank is fully charged, the temperature of the water is about $100^{\circ} \mathrm{C}$ at the top of it and about $50^{\circ} \mathrm{C}$ at its bottom. The hot water of the buffer is pumped to the plate heat exchanger (PHE) at a temperature of $100^{\circ} \mathrm{C}$ and it leaves the PHE with a temperature of $50^{\circ} \mathrm{C}$. A four-way mixing valve is used in order to adjust the flow-in temperature of the water in the PHE and in the buffer. In addition, the mass flow rate of the water streams is controlled by the rotational speed of the circulation pumps which are driven by variable speed motors. The thermal content of the water is given through the PHE to the working fluid of the Rankine cycle. The working fluid R134a is sucked by a scroll pump driven by a variable speed motor which controls the mass flow rate and it is guided into the PHE in order to receive the thermal power of the water. At the entrance of the scroll pump the working fluid has a temperature of $45^{\circ} \mathrm{C}$ at a pressure of 11.6 bar and after the 
compression the sub-cooled liquid enters the PHE at a temperature of $46.5^{\circ} \mathrm{C}$ with a pressure of 32.4 bar. The working fluid receives the thermal content of the water inside the PHE and it changes its phase from sub-cooled liquid to superheated vapour. It leaves the PHE having a temperature of $95^{\circ} \mathrm{C}$ and it comes into the scroll expander (turbine) where its thermal power is converted into useful mechanical work yielded at the shaft of the turbine. After the expansion, the working fluid exits the turbine with a temperature of $59.3^{\circ} \mathrm{C}$ (isentropic efficiency 70\%) and it enters into the air cooler at vapour state where it is fully condensed until it comes to saturated liquid state with a temperature of $45^{\circ} \mathrm{C}$. Then, it is collected inside the accumulator and hereinafter it is sucked again by the feed pump and so on. The main technical characteristics of the system are shown in Table 1.

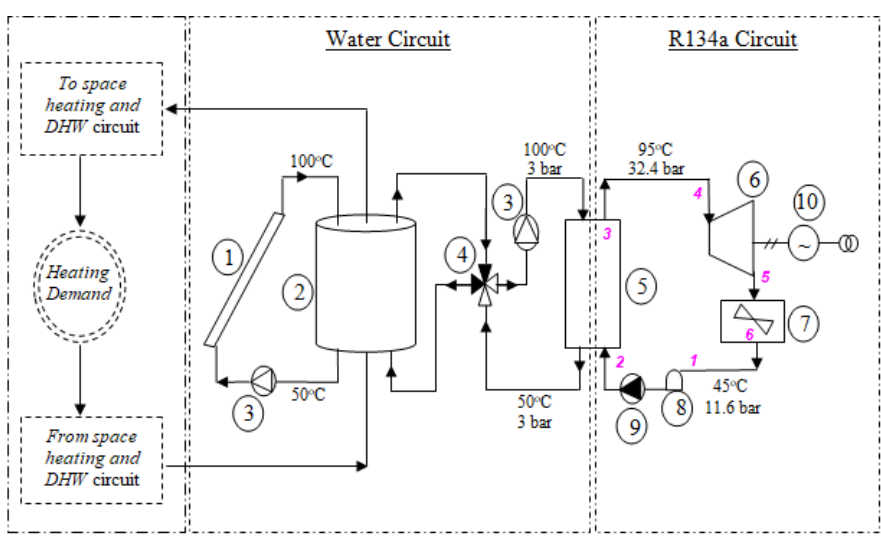

Figure 1. Schematic view of SORC system

1. Solar collectors, 2. Buffer (water storage tank), 3. Circulation pump (variable speed water pump), 4. Four way valve (mixing valve), 5. Generator (brazed plate heat exchanger), 6. Turbine (oil free scroll expander), 7. Condenser (air cooler with variable speed fans), 8. Liquid receiver, 9. Feed pump (variable speed scroll pump), 10. Doubly Fed Induction Generator

Table 1. The main technical characteristics of the systems

\begin{tabular}{|l|l|l|}
\hline Nominal Output: & themal $45 \mathrm{~kW}$ th & electrical $4 \mathrm{~kW}$. \\
\hline Total absorber area: & $76.75 \mathrm{~m}^{2}$ & vacuum tube solar collectors \\
\hline Buffer volume: & $4.95 \mathrm{~m}^{3}$ & thermally stratified water tank \\
\hline Circulation pumps: & $3 \mathrm{~W} / 20 \mathrm{~W}$ & variable speed water pump \\
\hline Generator: & $0.38 \mathrm{~m}^{2}$ & Brazed Plate Heat Exchanger \\
\hline Condenser: & $194.8 \mathrm{~m}^{2}$ & Air cooler (with variable speed fans) \\
\hline Feed pump: & $9.1 \mathrm{~cm}^{3} / \mathrm{rev}$ & variable speed scroll pump \\
\hline Turbine: & $73.6 \mathrm{~cm}^{3} / \mathrm{rev}$ & oil free scroll expander (hemi-hermetic) \\
\hline Water temperature: & max $100^{\circ} \mathrm{C}$ & min $50^{\circ} \mathrm{C}$ \\
\hline R134a & $95^{\circ} \mathrm{C} / 32.43 \mathrm{bar}$ & max temperature $/$ pressure \\
\hline R134a & $45^{\circ} \mathrm{C} / 11.60 \mathrm{bar}$ & $\min$ temperature $/$ pressure \\
\hline Min mass flow rate: & water $0.06 \mathrm{~kg} / \mathrm{s}$ & R134a $0.07 \mathrm{~kg} / \mathrm{s}$ \\
\hline Max mass flow rate: & water $0.25 \mathrm{~kg} / \mathrm{s}$ & R134a $0.29 \mathrm{~kg} / \mathrm{s}$ \\
\hline DFIG rotational speed: & $\operatorname{max~} 3000 \mathrm{rpm}$ & $\min 750 \mathrm{rpm}$ \\
\hline & & \\
\hline
\end{tabular}

\section{ANALYSIS OF SORC SYSTEM}

In order to clarify how the organic Rankine engine functions, a description of its operation is given on the (T-s) chart in Fig. 2. The states of the working fluid at each point of the cycle are shown in Table 2.
Table 2.States of the working fluid at each point of the Rankine cycle

\begin{tabular}{|c|c|c|c|c|c|}
\hline Index & Point & State & $\begin{array}{c}\text { Pressure } \\
(\mathrm{bar})\end{array}$ & $\begin{array}{c}\text { Temperature } \\
\left({ }^{\circ} \mathrm{C}\right)\end{array}$ & $\begin{array}{c}\text { Enthalpy } \\
(\mathrm{kJ} / \mathrm{kg})\end{array}$ \\
\hline 1 & $\begin{array}{c}\text { exit of the condenser } \\
\text { entrance of the feed pump }\end{array}$ & $\begin{array}{c}\text { saturated } \\
\text { liquid }\end{array}$ & 11.6 & 45.0 & 204.1 \\
\hline 2 & $\begin{array}{c}\text { exit of the feed pump } \\
\text { entrance of the generator }\end{array}$ & $\begin{array}{c}\text { subcooled } \\
\text { liquid }\end{array}$ & 32.4 & 46.5 & 205.9 \\
\hline 3 & $\begin{array}{c}\text { inside the generator } \\
4\end{array}$ & $\begin{array}{c}\text { saturated } \\
\text { vapour }\end{array}$ & 32.4 & 90.0 & 380.5 \\
\hline 5 & $\begin{array}{c}\text { exit of the generator } \\
\text { entrance of the turbine }\end{array}$ & $\begin{array}{c}\text { superheated } \\
\text { vapour }\end{array}$ & 32.4 & 95.0 & 388.2 \\
\hline 6 & $\begin{array}{c}\text { extrance of the condenser } \\
\text { inside the condenser }\end{array}$ & $\begin{array}{c}\text { superheated } \\
\text { vapour }\end{array}$ & 11.6 & 59.3 & 366.9 \\
\hline & saturated & 11.60 & 45.0 & 361.3 \\
\hline
\end{tabular}

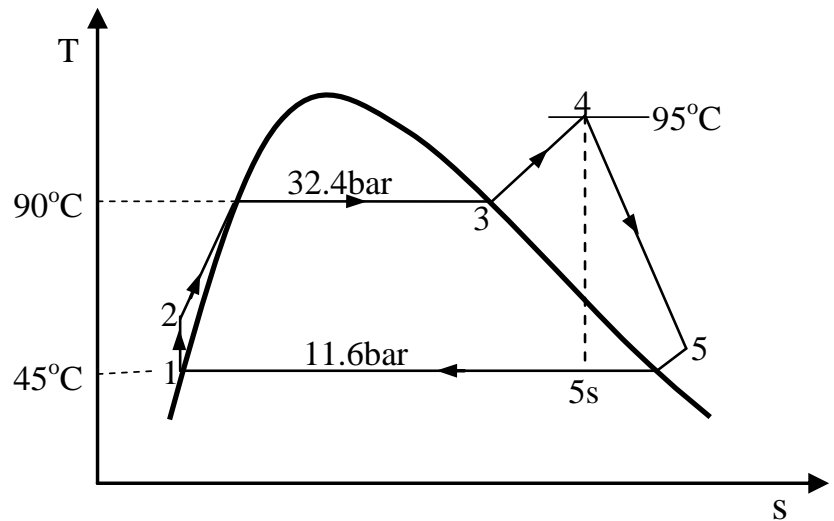

Figure 2. T-s chart of organic Rankine cycle

The thermodynamic efficiency of Rankine cycle is calculated by equation:

$\eta_{\mathrm{th}}=\left(\mathrm{w}_{\mathrm{t}}-\mathrm{w}_{\mathrm{p}}\right) / \mathrm{q}_{\mathrm{g}}=1-\left(\mathrm{h}_{5}-\mathrm{h}_{1}\right) /\left(\mathrm{h}_{4}-\mathrm{h}_{2}\right)$

where $\mathrm{w}_{\mathrm{t}}$ the work of the turbine, $\mathrm{w}_{\mathrm{p}}$ the work of the pump and $\mathrm{q}_{\mathrm{g}}$ the heat of the generator.

The efficiency of the solar collectors is given by (Eq. (2)) as [10]:

$\eta_{\text {coll }}=0.815-1.36 \frac{\Delta \mathrm{T}}{\mathrm{E}_{\mathrm{g}}}-0.0045 \frac{\Delta \mathrm{T}^{2}}{\mathrm{E}_{\mathrm{g}}}$

The temperature difference $\Delta \mathrm{T}$ between the ambient air dry bulb temperature $\theta_{\mathrm{a}}$ and the collector's surface mean temperature $\theta_{\mathrm{m}}$ is $\Delta \mathrm{T}=\theta_{\mathrm{m}}-\theta_{\mathrm{a}}$. The flow-in temperature $\mathrm{t}_{\mathrm{w}, \text { in }}$ and the flow-out temperature $\mathrm{t}_{\mathrm{w}, \text { out }}$ of the water in the solar array are taken $50^{\circ} \mathrm{C}$ and $100^{\circ} \mathrm{C}$ respectively, thus, the collector's surface mean temperature may be approximated as $\theta_{\mathrm{m}}=\left(\mathrm{t}_{\mathrm{w}, \text { in }}+\mathrm{t}_{\mathrm{w}, \text { out }}\right) / 2=75^{\circ} \mathrm{C}$.

The solar irradiance $\mathrm{E}_{\mathrm{g}}$ is converted into thermal power which is transferred to the water through the collectors and as a result:

$\eta_{\text {coll }} E_{g} A=\dot{m}_{w} c_{p, w}\left(t_{w, \text { in }}-t_{w, o u t}\right)$

The absorber area is totally $\mathrm{A}=76.75 \mathrm{~m}^{2}$ and the specific heat of the water at $75^{\circ} \mathrm{C}$ is $c_{p, w}=4185 \mathrm{~J} / \mathrm{kgK}$. Consequently, by combining the previous two equations it comes that the mass flow rate of the water is:

$\dot{\mathrm{m}}_{\mathrm{w}}=\frac{62.55 \mathrm{E}_{\mathrm{g}}-104.38\left(75-\theta_{\mathrm{a}}\right)-0.3454\left(75-\theta_{\mathrm{a}}\right)^{2}}{209250}$ 
It is considered that when equilibrium is achieved, the mass flow rate of the water is the same for both sides of the arrangement. The mass flow rate of the water in the solar array and in the PHE as well is regulated by a variable speed circulation pump on each side while a four-way mixing valve regulates the flow-in and the flow-out temperatures of the water in the PHE and in the buffer. The stability of the system's operation against the stochastic behaviour of the solar flux is supported by the thermal inertia provided by the buffer. The hot water comes from the solar array inside the buffer and it goes from the top of the buffer to the four-way valve having a temperature $\mathrm{T}_{\max }$ while the cold water returns from the four-way valve inside the buffer and it leaves the bottom of the buffer for the array having a temperature $T_{\text {min }}$. The rate of change of the mean temperature of the water inside the tank over a period of time is $\Delta \mathrm{T} / \Delta \mathrm{t}$ and by making the energy balance over the adiabatic tank, it can be written that:

$\mathrm{mc} \Delta \mathrm{T} / \Delta \mathrm{t}=\dot{\mathrm{m}}_{\mathrm{w}} \mathrm{c}_{\mathrm{p}}\left(\mathrm{T}_{\max }-\mathrm{T}_{\min }\right)$

Considering that $\mathrm{c}=\mathrm{c}_{\mathrm{p}}, \Delta \mathrm{T}=(\mathrm{T} \max +\mathrm{Tmin}) / 2-\mathrm{Tmin}=(\mathrm{Tmax}-\mathrm{Tmin}) / 2$ then the previous equation gives that $\Delta \mathrm{t}=\mathrm{m} / 2 \dot{\mathrm{m}}_{\mathrm{w}}$ which is the time (in seconds) of charge or discharge of the tank, $(\mathrm{m}=4851 \mathrm{~kg}$ the mass of water in the buffer at mean temperature $75^{\circ} \mathrm{C}$ ). Finally, the time (in minutes) of charge/discharge of the buffer is:

$\Delta \mathrm{t}=\frac{40.425}{\dot{\mathrm{m}}_{\mathrm{w}}}$

The solar heat is transferred from the water to the R134a inside the generator (PHE). The thermal losses during the several thermal processes are considered negligible. Therefore:

$\dot{\mathrm{m}}_{\mathrm{w}}\left(\mathrm{h}_{\mathrm{w}, \text { in }}-\mathrm{h}_{\mathrm{w}, \text { out }}\right)=\dot{\mathrm{m}}_{\mathrm{r}}\left(\mathrm{h}_{4}-\mathrm{h}_{2}\right)$

and the mass flow rate of the $\mathrm{R} 134 \mathrm{a}$ is:

$\dot{\mathrm{m}}_{\mathrm{r}}=1.151 \dot{\mathrm{m}}_{\mathrm{w}}$

The work rate of turbine is:

$\dot{\mathrm{W}}_{\mathrm{t}}=\dot{\mathrm{m}}_{\mathrm{r}}\left(\mathrm{h}_{4}-\mathrm{h}_{5}\right)$ or $\quad \dot{\mathrm{W}}_{\mathrm{t}}=24.52 \dot{\mathrm{m}}_{\mathrm{w}}$

The mass flow rate of the working fluid is related to the rotational speed of the turbine. The rotational speed $\mathrm{N}_{t}$ of the turbine is calculated by the following equation:

$\dot{\mathrm{m}}_{\mathrm{r}}=\eta_{\mathrm{v}} \rho_{\mathrm{r}, 4} \mathrm{~N}_{\mathrm{t}} \mathrm{V}_{\mathrm{t}}$ or $\mathrm{N}_{\mathrm{t}}=126.55 \dot{\mathrm{m}}_{\mathrm{w}}$

where $\rho_{\mathrm{r}, 4}=190.114 \mathrm{~kg} / \mathrm{m}^{3}$ the density of the vapour at the entrance of the turbine, $V_{\mathrm{t}}=73.6 \times 10^{-6} \mathrm{~m}^{3}$ the displacement volume which is the chamber's volume when the expansion chamber is fully closed given by the manufacturer, $\eta_{\mathrm{v}}=0.65$ the volumetric efficiency of the turbine given also by the manufacturer [11].

The heat rejected by the condenser to the ambient air is:

$\dot{\mathrm{Q}}_{\mathrm{c}}=\dot{\mathrm{m}}_{\mathrm{r}}\left(\mathrm{h}_{5}-\mathrm{h}_{1}\right)$ or $\dot{\mathrm{Q}}_{\mathrm{c}}=187.38 \dot{\mathrm{m}}_{\mathrm{w}}$

The mechanical power absorbed by an isentropic compression is:

$\dot{\mathrm{W}}_{\mathrm{p}}=\dot{\mathrm{m}}_{\mathrm{r}}\left(\mathrm{h}_{2}-\mathrm{h}_{1}\right)$ or $\dot{\mathrm{W}}_{\mathrm{p}}=2.072 \dot{\mathrm{m}}_{\mathrm{w}}$

The rotational speed $\mathrm{N}_{\mathrm{p}}$ of the feed pump is:

$\dot{\mathrm{m}}_{\mathrm{r}}=\eta_{\mathrm{v}} \rho_{\mathrm{r}, 1} \mathrm{~N}_{\mathrm{p}} \mathrm{V}_{\mathrm{p}}$ or $\mathrm{N}_{\mathrm{p}}=189.73 \dot{\mathrm{m}}_{\mathrm{w}}$

where $\rho_{\mathrm{r}, 1}=1111.1 \mathrm{~kg} / \mathrm{m}^{3}$ the density of the liquid at the entrance of the feed pump, $\mathrm{V}_{\mathrm{p}}=9.1 \times 10^{-6} \mathrm{~m}^{3}$ the displacement volume which is the chamber's volume when the compression chamber is fully opened given by the manufactured, $\eta_{\mathrm{v}}=0.60$ the volumetric efficiency of the pump given also by the manufactured [11].

A four pole Doubly Fed Induction Generator (DFIG) with rated output at $4 \mathrm{~kW} / 50 \mathrm{~Hz}$ is used. The shaft of the turbine is connected with the alternator through a chain drive with a transmission ratio $\mathrm{i}=1: 1.6$. The rotational speed of the alternator is:

$\mathrm{N}=(1-\mathrm{s}) \mathrm{f} / \mathrm{p}$

where the frequency of the grid is $\mathrm{f}=50 \mathrm{~Hz}$, the number of pole pairs is $\mathrm{p}=2$ and the slip is $\mathrm{s}$.

As aforementioned the rotational speed of the turbine is $\mathrm{N}_{\mathrm{t}}=126.55$ $\dot{\mathrm{m}}_{\mathrm{w}}$ and obviously $(1-\mathrm{s}) \mathrm{f} / \mathrm{p}=1.6126 .55 \dot{\mathrm{m}}_{\mathrm{w}}$ and so finally the slip is:

$\mathrm{s}=1-8.0992 \dot{\mathrm{m}}_{\mathrm{w}}$

The rotational speed of the electric generator is varied in proportion with the slip, so, the speed of the alternator is controlled by adjusting the slip. The control is achieved by regulating the excitation current which feeds the rotor by giving or taking from it the appropriate amount of electrical power. The current flows to or from the rotor depending on the conditions but in any case the stator supplies electrical power to the PPC grid at constant voltage and frequency. In over-loading, the current flows from the rotor to the grid but on the contrary in under-loading it is the grid that provides power to the rotor. The rotational speed in DFIG can vary by $\pm 50 \%$ from the synchronous speed of the machine and the power generated can be twice the rated power of the machine provided that the prime mover runs at the double speed of the synchronous speed of the generator. At this point, it is noted that since $-1<\mathrm{s}<1$ then $0<\dot{\mathrm{m}}_{\mathrm{w}}<0.247$. In conclusion, the rotational speed of the alternator is:

$\mathrm{N}=1.6 \cdot 126.55 \dot{\mathrm{m}}_{\mathrm{w}} \quad$ or $\quad \mathrm{N}=202.48 \dot{\mathrm{m}}_{\mathrm{w}}$

The alternator's efficiency is taken $88.4 \%$ (given by the manufacturer [12]) and reasonably assuming that the losses in the converters will be about $10 \%$, the overall efficiency of the DFIG arrangement will be $\eta_{\mathrm{el}}=0.884 \times 0.9=0.8$. As a result, the final electrical output is $\dot{\mathrm{P}}_{\mathrm{el}}=\eta_{\mathrm{el}}$ $\dot{\mathrm{W}}_{\mathrm{t}}=0.8 \dot{\mathrm{W}}_{\mathrm{t}}$ and as aforementioned $\dot{\mathrm{W}}_{\mathrm{t}}=24.52 \dot{\mathrm{m}}_{\mathrm{w}}$. Finally, the electrical power output of the system to the PPC grid will be:

$\dot{\mathrm{P}}_{\mathrm{el}}=\eta_{\mathrm{el}} \dot{\mathrm{W}}_{\mathrm{t}}=19.616 \dot{\mathrm{m}}_{\mathrm{w}}$

The overall efficiency of the system is the ratio of the final output to the total input power. The input power is provided by the Greek sun and it will be taken as the solar irradiance $\mathrm{E}_{\mathrm{g}}$ multiplied by the total absorber area A. The output power is the electrical power given to the grid by the asynchronous machine minus the power consumed during the several processes. The power consumed by the variable speed air fans is negligible while the power consumed by variable speed circulation pumps has been calculated, therefore the net output power is:

$\dot{\mathrm{P}}_{\text {out }}=\dot{\mathrm{P}}_{\mathrm{el}}-\dot{\mathrm{W}}_{\mathrm{p}}=17.544 \dot{\mathrm{m}}_{\mathrm{w}}$

The overall solar-to-electricity efficiency of the system is:

$\eta_{\text {tot }}=\dot{\mathrm{P}}_{\text {out }} /\left(\mathrm{E}_{\mathrm{g}} \mathrm{A}\right)=0.22858 \dot{\mathrm{m}}_{\mathrm{w}} / \mathrm{E}_{\mathrm{g}}$

Finally, the overall efficiency of the system is:

$\eta_{\text {tot }}=\frac{0.0683 \mathrm{E}_{\mathrm{g}}-0.1140\left(75-\theta_{\mathrm{a}}\right)-0.00038\left(75-\theta_{\mathrm{a}}\right)^{2}}{\mathrm{E}_{\mathrm{g}}}$ 
where $\mathrm{E}_{\mathrm{g}}$ the solar irradiance (in $\mathrm{W} / \mathrm{m}^{2}$ ) and $\theta_{\mathrm{a}}$ the ambient air temperature (in ${ }^{\circ} \mathrm{Cdb}$ ).

\section{SIMULATION OF THE OPERATION IN ATHENS}

In the present solar Rankine system, the influence of several parameters on the behavior of the system performance was studied. The following assumptions were made in order to estimate the efficiency.

- The thermal losses during the several processes are negligible

- The power consumed by the variable speed air fans and by the variable speed circulation pumps is negligible

- The compression of the R134a is isentropic

- The electrical loss in the converters is $10 \%$

It is considered that the system is installed in a building which has the following characteristics:

- Nine-storied building in Athens

- Perimeter: $25 \times 15$ mxm

- Total height: 9x3 m=27 m

- Total surface area: $9 \times(25 \times 15 \mathrm{mxm})=3375 \mathrm{~m}^{2}$

- Total volume: $27 \mathrm{mx} 25 \mathrm{mx} 15 \mathrm{~m}=10125 \mathrm{~m}^{3}$

- Envelope area: $2 \times(25 \mathrm{~m}+15 \mathrm{~m}) \times 27 \mathrm{~m}+2 \mathrm{x}(25 \mathrm{x} 15) \mathrm{m}^{2}=2910 \mathrm{~m}^{2}$

- Heat loss coefficient $\mathrm{U}-$ value $=1.09 \mathrm{~W} / \mathrm{m}^{2} \mathrm{~K}$ [15] for buildings with total area to volume ratio at $0.3 \mathrm{~m}^{2} / \mathrm{m}^{3}$ )

The space heating demand (in $\mathrm{Wh}$ ) for this building is calculated as:

U-value x Envelope area x HDD x 24 h/day

The total monthly solar radiation in $\mathrm{kWh} / \mathrm{m}^{2}$ in horizontal plane in Athens, the mean monthly dry-bulb air temperature in ${ }^{\circ} \mathrm{C} \mathrm{db}$ during the daylight and heating degree-days (HDD) per month in Athens at reference temperature $18^{\circ} \mathrm{C}$ are shown on the Table 3 [16]. Also the mean monthly sunshine duration in Athens is shown at a corresponding study [17].

According to the Table 3 the annual energy yield of the system per absorber area is:

Thermal energy yield $\quad 1098 \mathrm{kWh}_{\mathrm{th}} / \mathrm{m}^{2}$

Electrical energy yield $\quad 91.67 \mathrm{kWh} / \mathrm{h}^{2}$

The annual energy yield of the system (with an absorber area of $76.75 \mathrm{~m}^{2}$ ) is:

Thermal energy yield $\quad 84272 \mathrm{kWh}_{\text {th }}$

Electrical energy yield $\quad 7036 \mathrm{kWh}_{\mathrm{el}}$

Table 3. The data and result output

\begin{tabular}{|c|c|c|c|c|c|c|c|c|c|}
\hline \multirow{3}{*}{$\begin{array}{l}\overline{\bar{z}} \\
\frac{1}{2}\end{array}$} & \multirow{3}{*}{ 全 } & \multirow{2}{*}{ 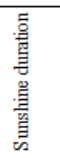 } & \multirow{2}{*}{ 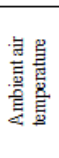 } & \multicolumn{2}{|c|}{ Solar } & \multicolumn{2}{|c|}{ Efficiency } & \multicolumn{2}{|c|}{$\begin{array}{l}\text { Energy yield per } \\
\text { absorber area }\end{array}$} \\
\hline & & & & 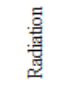 & 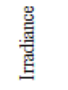 & $\frac{3}{2}$ & $\stackrel{\frac{\gamma}{2}}{=}$ & $\begin{array}{l}\text { 䇾 } \\
\text { 总 }\end{array}$ & 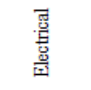 \\
\hline & & hours & ${ }^{C} \mathrm{~d} \mathrm{db}$ & $\mathrm{kWhm}^{2}$ & $\mathrm{~W} / \mathrm{m}^{2}$ & $\%$ & $\%$ & $\mathrm{kWh}_{\alpha} \mathrm{m}^{2}$ & $\mathrm{kWh} / \mathrm{m}^{2}$ \\
\hline Jan & 239 & 123.4 & 11.3 & 63 & 511 & 60.95 & 5.09 & 38.40 & 3.21 \\
\hline Feb & 207 & 136.8 & 11.7 & 79 & 577 & 63.47 & 5.30 & 50.14 & 4.19 \\
\hline Mar & 177 & 177.6 & 13.4 & 118 & 663 & 66.28 & 5,54 & 78.21 & 6.51 \\
\hline Apr & 60 & 227.3 & 17.1 & 154 & 679 & 67.68 & 5.65 & 104.23 & 8.72 \\
\hline May & 0 & 297.0 & 21.8 & 195 & 658 & 68,57 & 5.73 & 133.71 & 11.19 \\
\hline Jun & 0 & 330.9 & 26.5 & 214 & 647 & 69.66 & 5.82 & 149.07 & 12.45 \\
\hline Jul & 0 & 370.2 & 29.2 & 222 & 601 & 69,56 & 5.81 & 154.42 & 12.92 \\
\hline Aug & 0 & 347.8 & 29.2 & 203 & 583 & 69.19 & 5.78 & 140.45 & 11.71 \\
\hline Sept & 0 & 276.9 & 25.5 & 153 & 551 & 67.28 & 5.62 & 102.94 & 8.57 \\
\hline Oct & 0 & 204.9 & 20.7 & 109 & 532 & 65.12 & 5.44 & 70.98 & 5.93 \\
\hline Nov & 78 & 159.6 & 16.4 & 71 & 443 & 60.02 & 5.01 & 42.61 & 3.54 \\
\hline Dec & 186 & 125.5 & 13.0 & 56 & 444 & 58.60 & 4.89 & 32.82 & 2.73 \\
\hline 焉鄫 & Total & Mean & Mean & Total & Mean & Mean & Mean & Total & Total \\
\hline & 947 & 231.5 & 19.7 & 1637 & 574 & 65.53 & 5.47 & 1098 & 91.67 \\
\hline
\end{tabular}

The Fig. 3 is formed by using the data of the Table 3 by dividing the mean monthly solar radiation in $\mathrm{kWh} / \mathrm{m}^{2}$ with the mean monthly sunshine period in hours. It is also shown the mean monthly dry-bulb air temperature in ${ }^{\circ} \mathrm{C} \mathrm{db}$. It is obvious that the maximum mean monthly dry-bulb air temperature occurs in June-August and the maximum mean monthly solar irradiance in April.

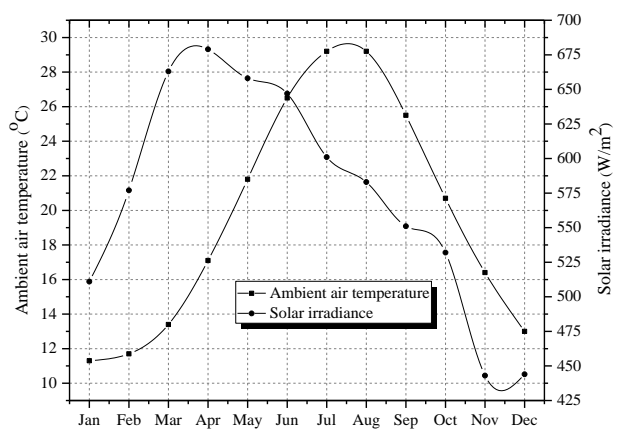

Figure 3. Mean monthly solar irradiance on horizontal plane and mean monthly ambient air temperature in daylight in Athens

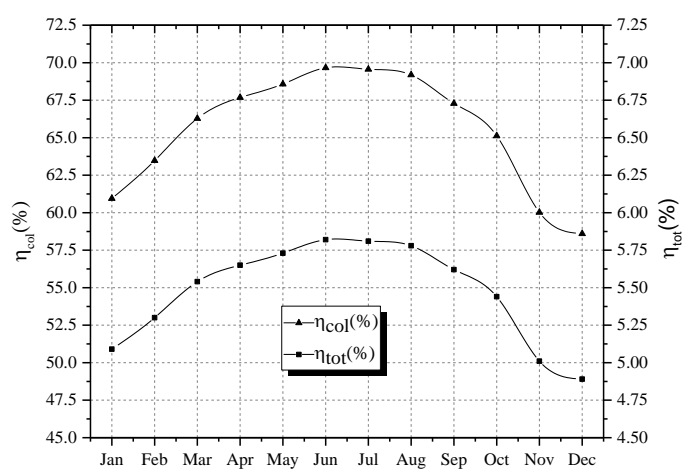

Figure 4. The overall and the collector's mean monthly efficiency

In the following Fig. 4, the mean monthly overall $\eta_{\text {tot }}$ and collector efficiency $\eta_{\text {coll }}$ are presented according to above calculations (Eq. (2) and Eq. (20)). It is obvious that the maximum values are presented during the summer and maximize the month of June.

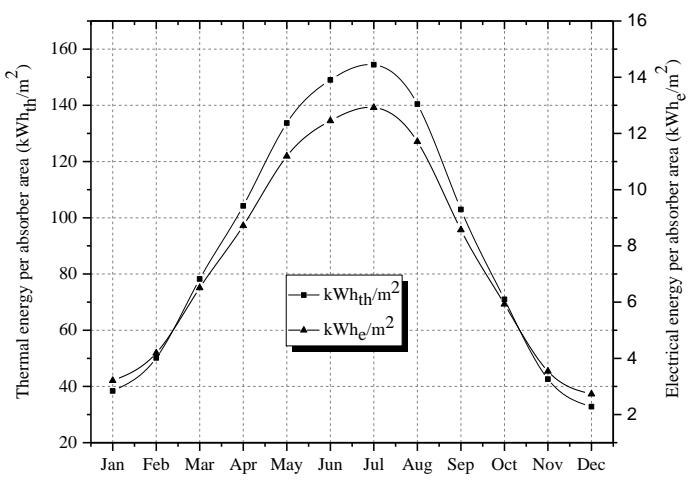

Figure 5. The monthly thermal and electrical energy yield per absorber area 
The Fig. 5 is formed multiplying the mean monthly solar radiation in $\mathrm{kWh} / \mathrm{m}^{2}$ with the mean monthly overall $\eta_{\text {tot }}$ and collector efficiency $\eta_{\text {coll }}$, respectively. Both the mean monthly thermal energy and electrical energy per absorber area present the peak in July.

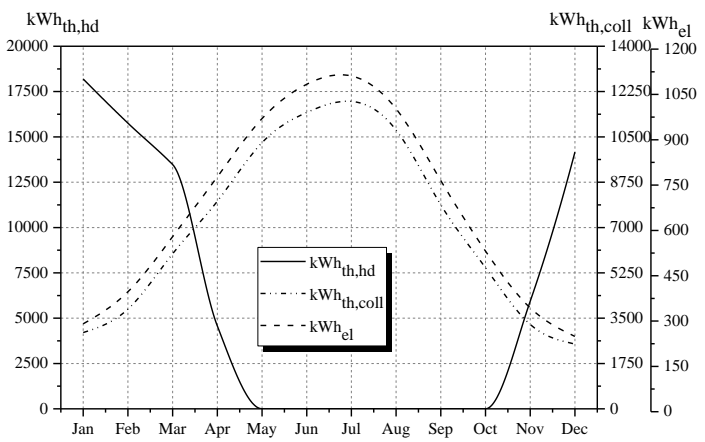

Figure 6. The monthly thermal / electrical energy yield vs the building's heating demand

In the above Fig. 6 the monthly thermal energy yield from collector $\mathrm{kWh}_{\mathrm{th}, \text { coll }}$ is calculated multiplying the mean monthly solar irradiance $E_{g}$ with the mean monthly collector efficiency $\eta_{\text {coll }}$, the heating degree-days (HDD) per month, the mean monthly sunshine duration in Athens and the absorber area A. The monthly heating demand of the building $\mathrm{kWh}_{\mathrm{th}, \mathrm{hd}}$ is calculated multiplying the overall heat loss coefficient of a building U-value with envelope area, the heating degree-days (HDD) per month and $24 \mathrm{~h} /$ day. The monthly electrical $\mathrm{kWh}_{\mathrm{el}}$ energy yield of the system is calculated multiplying the mean monthly electrical power $\dot{\mathrm{P}}_{\mathrm{el}}$ (Eq. (17)) with the mean monthly sunshine duration in Athens.

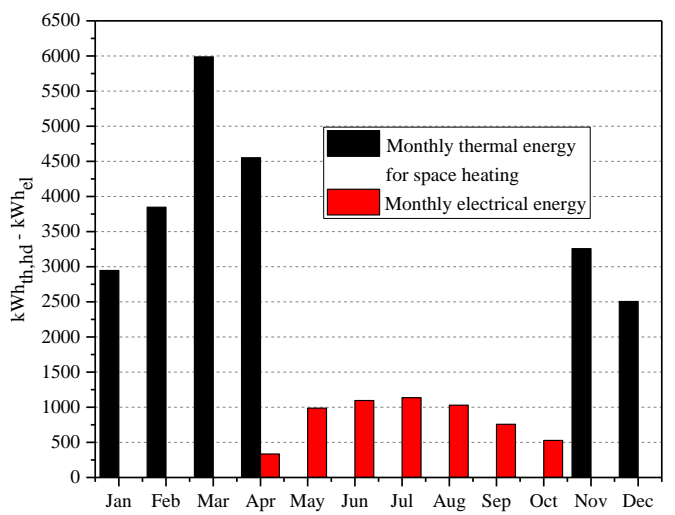

Figure.7. The monthly thermal energy yield used for space heating and the monthly electrical energy yield

In the Fig.7 the monthly thermal energy used for space heating $\mathrm{kWh}_{\mathrm{th}, \mathrm{hd}}$ and the monthly electrical energy $\mathrm{kWh}_{\mathrm{el}}$ of the system are presented when the solar collectors are used in order to cover primarily the space heating demands of the building.

In order to estimated the useful monthly electrical energy during the months April-October, multiply the respective monthly electrical energy $\mathrm{kWh}_{\mathrm{el}}$ with the difference of the monthly thermal energy from collector $\mathrm{kWh}_{\text {th,coll }}$ and the monthly thermal energy of space heating $\mathrm{kWh}_{\mathrm{th}, \mathrm{hd}}$ and divided by monthly thermal energy from collector $\mathrm{kWh}_{\text {th,coll }}$.
When the solar thermal arrangement is primarily used to cover the heating demand the annual energy yield of the system is:

Thermal energy yield used for space heating

23097

$\mathrm{kWh}_{\text {th,hd }}$

Electrical energy production

5869

$\mathrm{kWh}_{\mathrm{el}}$

\section{CONCLUSIONS}

In the present study a solar Rankine system with R134a as working fluid for a building in Athens is presented and also its operation is analyzed. During of the months of the year in Athens the SORC system can be operated with efficiency from 0.049 to 0.058 while the solar collector efficiency has values from 0.586 to 0.697 . The thermodynamic efficiency of Rankine is calculated at 0.107 . The performance of the SORC system strongly depends on the climate conditions of the area which is installed due to its overall efficiency is a function of the solar radiation and the ambient air temperature.

Having in mind that the total electricity demand in Greece is less than $55 \mathrm{TWh}$ per year and about the $1 / 3$ of which concerns the consumption in households, then the conclusion is that $20 \mathrm{~m}^{2}$ of absorber area is enough to cover the yearly electricity need of one person in a Greek residence.

In this work, commercially available technologies are employed and a simple and practical SORC model that can be integrated into buildings is attained. It is proven that the Greek solar potential is adequate to provide notable amounts of electric energy via ORC during the long period of the year that the solar thermal arrangements can produce huge amounts of thermal energy while the heating demand of the buildings is low. This conclusion is based on the climatic data of Athens which are representative for the Greek region. The combi-systems, which provide hot water for usage and space heating in buildings, hold a considerable share of the Greek market regarding the solar thermal systems. As it is shown in the in the present work, the Greek climate is ideal for coupling a combi-system with an ORC. The demand for space heating is zero from May to October and in addition the demand for DHW also becomes very low because during this period the water which comes from the supply has relatively higher temperatures than it has during the cold months of the year. Furthermore, during the months that the heating demands are very low or zero the solar radiation is much higher than it is during the months that the need for heating is high.

Having this fact in mind, a typical building was taken as an example and it was examined and the results were particularly interesting. According to this example, if a combi-system installed then almost the one third of the demand in space heating can be covered but almost the one half of the annual energy yield from the solar thermal is not used because during the hot months the heating demand is zero. So, useful thermal yield is not only wasted but it also becomes very harmful because it is detrimental for the solar thermal arrangement as a whole due to the huge increase of the water's pressure and temperature inside the pipes, the solar collectors, the storage tank etc. The solar array can cover only about the $30 \%$ of the demand for space heating while the $46 \%$ of the annual thermal yield from the collectors would be wasted without the presence of the Rankine engine. The Rankine engine can be fed by this waste and interesting amounts of electricity can be produced.

In conclusion, the SORC is a very promising option for Greek commercial and residential buildings as it is proven in this preliminary evaluation. The integration of SORC in Greek commercial and residential buildings can be achieved by using easyto-find and user-friendly machinery with relatively low cost.

A

$\mathrm{c}_{\mathrm{p}}$

DFIG
NOMENCLATURE

Total absorber area $\left(\mathrm{m}^{2}\right)$

Specific heat $\left(\mathrm{kJkg}^{-1} \mathrm{~K}^{-1}\right)$

Doubly fed induction generator 


\begin{tabular}{|c|c|}
\hline DHW & Domestic hot water \\
\hline $\mathrm{E}_{\mathrm{g}}$ & Solar irradiance $\left(\mathrm{Wm}^{-2}\right)$ \\
\hline$f^{\circ}$ & frequency $\left(\mathrm{s}^{-1}\right)$ \\
\hline HDD & Heating day-degree \\
\hline $\mathrm{h}$ & Specific enthalpy $\left(\mathrm{kJkg}^{-1}\right)$ \\
\hline $\mathrm{N}$ & Rotational speed (rps) \\
\hline $\mathrm{m}$ & Mass $(\mathrm{kg})$ \\
\hline$\dot{\mathrm{m}}$ & Mass flow rate $\left(\mathrm{kgs}^{-1}\right)$ \\
\hline ORC & Organic Rankine cycle \\
\hline$\dot{\mathrm{P}}_{\mathrm{el}}$ & Electrical power $(\mathrm{kW})$ \\
\hline PHE & Plate heat exchanger \\
\hline PPC & Public Power Corporation \\
\hline$\dot{\mathrm{Q}}$ & Heat rate $(\mathrm{kW})$ \\
\hline q & Heat $\left(\mathrm{kJkg}^{-1}\right)$ \\
\hline SORC & Solar organic Rankine cycle \\
\hline s & Slip, Specific entropy $\left(\mathrm{kJkg}^{-1} \mathrm{~K}^{-1}\right)$ \\
\hline $\mathrm{T}$ & Temperature $\left({ }^{\circ} \mathrm{C}\right)$ \\
\hline $\mathrm{t}$ & Time (sec, $\min )$ \\
\hline U-value & $\begin{array}{l}\text { Overall heat loss coefficient of a building } \\
\left(\mathrm{Wm}^{-2} \mathrm{~K}^{-1}\right)\end{array}$ \\
\hline $\mathrm{V}$ & Displacement volume $\left(\mathrm{m}^{3}\right)$ \\
\hline$\dot{\mathrm{W}}$ & Work rate $(\mathrm{kW})$ \\
\hline $\mathrm{W}$ & Work $\left(\mathrm{kJkg}^{-1}\right)$ \\
\hline \multicolumn{2}{|c|}{ Greek symbols } \\
\hline$\Delta$ & Difference \\
\hline$\eta$ & Efficiency \\
\hline$\theta$ & Temperature $\left({ }^{\circ} \mathrm{C}\right)$ \\
\hline$\rho$ & Density $\left(\mathrm{kgm}^{-3}\right)$ \\
\hline \multicolumn{2}{|c|}{ Subscripts } \\
\hline $1,2 \ldots$ & Rankine cycle locations \\
\hline $\mathrm{a}$ & Ambient \\
\hline coll & Collector \\
\hline el & Electrical \\
\hline g & Generator \\
\hline $\mathrm{m}$ & Mean \\
\hline $\mathrm{p}$ & Pump \\
\hline $\mathrm{r}$ & Refrigerant R134a \\
\hline$t$ & Turbine \\
\hline th & Thermodynamic \\
\hline tot & Total \\
\hline $\mathrm{v}$ & Volumetric \\
\hline $\mathrm{w}$ & Water \\
\hline
\end{tabular}

\section{REFERENCES}

[1] T. Saitoh, N. Yamada, S. Wakashima, Solar Rankine Cycle System Using Scroll Expander, J Environ Eng 2(4) (2007) 708719.

[2] S. Quoilin, Sustainable Energy Conversion Through the Use of Organic Rankine Cycles for Waste Heat Recovery and Solar Applications, PhD thesis, Faculty of Applied Science of the University of Liege (2011).

[3] V.M. Nguyen, P.S. Doherty, S.B. Riffat, Development of a prototype low-temperature Rankine cycle electricity generation system, Appl Therm Eng 21 (2001) 169-181.

[4] D. Manolakos, G. Papadakis, Sh. Essam, S. Kyritsis, K. Bouzianas, Design of an autonomous low-temperature solar Rankine for reverse osmosis desalination, Desalination 183 (2005) 73-80.

[5] D. Manolakos, G. Papadakis, S. Kyritsis, K. Bouzianas, Experimental evaluation of an autonomous low-temperature solar Rankine for reverse osmosis desalination, Desalination 203 (2007) 366-374.
[6] F. Calise, M.D. d'Accadia, M. Vicidomini, M. Scarpellino, Design and simulation of a prototype of a small-scale solar CHP system based on evacuated flat-plate solar collectors and Organic Rankine Cycle, Energ Convers Manage 90 (2015) 347363.

[7] F.B. Tchanche, G. Papadakis, G. Lambrinos, A. Frangoudakis, Fluid selection for a low temperature Solar Organic Rankine Cycle, Appl Therm Eng 29(11-12) (2009) 2468-2476.

[8] A. Schuster, S. Karellas, E. Kakaras, H. Spliethoff, Energetic and economic investigation of Organic Rankine Cycle applications, Appl Therm Eng 29(8-9) (2009) 1809-1817.

[9] ASHRAE Standing Standard Project Committee 34. Designation and Safety Classifications of Refrigerants. Addendum $\mathrm{f}$ to ANSI/ASHRAE Standard 34-2019; 2019.

[10] Viessmann Gmbh. Available. http://www.viessmann.de/de/einzweifamilienhaus

[11] AirSquared Manufacturing Inc., Scroll Expanders and Compressors. $\quad$ http://www.airsquared.com/wpcontent/uploads/2011/10/e22h38n425-web.pdf, 2018

[12] Valiadis Hellenic Motors, Asynchronous machine. http://www.valiadis.gr, 2018

[13] D.A. Kouremenos, K.A. Antonopoulos, E.D. Rogdakis, Performance of solar $\mathrm{NH}_{3} / \mathrm{H}_{2} \mathrm{O}$ absorption cycle in the Athens are, Sol Energy 35(3) (1985) 259-269.

[14] D.A. Kouremenos, K.A. Antonopoulos, E.S. Domazakis, Solar radiation correlation for the Athens area, Sol Energy 39(3) (1987) 187-195.

[15] Technical Chamber of Greece, Technical Directive TOTEE 20701-1/2010, Athens (2010).

[16] Technical Chamber of Greece, Technical Directive TOTEE 20701-3/2010, Athens (2010).

[17] A. Matzarakis, V. Katsoulis, Sunshine Duration in Greece, $7^{\text {th }}$ Panhellenic (International) Conference of Meteorology, Climatology and Atmospheric Physics. http://www.urbanclimate.net/matzarakis/papers/matzarakis_kat soulis_2005_cyprus.pdf, 2004. 